Kaznacheieva Tetiana

PhD in Arts, assistant professor

The Department of Common and Specialized Piano

A. V. Nezhdanova Odessa State Musical Academy

ORCID: 0000-0002-8692-2844

itaniamusic@gmail.com

\title{
THE SYNTHESIS OF ARTS IN THE GENRE OF OPERA-BALLET
}

The purpose of the work is to research the interaction and historical role of the musical, choreographic and dramatic arts in the formation of a synthetic genre of opera-ballet. Consideration of the characteristic features of the synthesis of arts is based on the analysis of the samples of this genre and its embodiment in the modern cultural space. Methodology. Historical, comparative approaches and the method of interdisciplinary analysis have been applied, which enables us to determine the transformation of the interaction of musical, stage and dance components of the genre of opera-ballet. The scientific novelty of the study is to consider the genre of opera-ballet in terms of interspesific connections of musical, dance and dramatic arts. The use of the concept of a suite dance form deepens an idea of a generalization of the genesis and ways of development of this genre. Conclusions. The analysis of the significant samples of the opera-ballet shows that this particular genre represents a unique synthesis of arts, which enhances drama, deepens the character of the play and creates its new image integrity. The genre of opera-ballet gives an opportunity to expose the artistic interrelations of different artistic epochs in a new way. Successful modern performances testify to its relevance and vitality, as well as open future prospects for the contemporary development.

Key words: synthesis, opera-ballet, suite dance form, comedy-ballet, tragedy-ballet, phantasmagoria.

Казначеєва Тетяна Олександрівна, кандидат мистецтвознавства, в. о. доцента кафедри загального та спеціалізованого фортепіано Одеської національної музичної академії ім. А. В. Нежданової

Синтез мистецтв у жанрі опери-балету

Мета роботи - дослідити взаємодію та історичну роль музичного, хореографрічного і драматичного видів мистецтв у формуванні синтетичного жанру опери-балету. Розгляд характерних ознак синтезу мистецтв ґрунтується на основі аналізу визначних зразків цього жанру та на його втіленні у сучасному культурному просторі. Методологія. Застосовано історичний, компаративний підходи та метод інтердисциплінарного аналізу, що надає можливість визначити трансформацію взаємодії музичного, сценічного та танцювального компонентів жанру опери-балету. Наукова новизна дослідження полягає в розгляді жанру опери-балету в ракурсі міжвидових зв'язків музичного, танцювального та драматичного мистецтв. Використання поняття сюїтної танцювальної фрорми поглиблює уявлення щодо узагальнення генезису та шляхів розвитку зазначеного жанру. Висновки. Аналіз специфріки показових зразків опери-балету дозволяє відзначити, що цей особливий жанр репрезентує унікальний синтез мистецтв, завдяки якому посилюється драматизм, поглиблюється характерність вистави та утворюється її нова образна цілісність. Жанр опери-балету надає можливість по-новому розкрити художні взаємозв'язки різних творчих епох. Успішні сучасні постановки свідчать про його актуальність та життєздатність, а також відкривають подальші перспективи для новітнього розвитку.

Ключові слова: синтез, опера-балет, сюїтна танцювальна фрорма, комедія-балет, трагедія-балет, франтасмагорія.

Казначеева Татьяна Александровна, кандидат искусствоведения, и. о. доцента кафедры общего и специализированного фортепиано Одесской национальной музыкальной академии им. А. В. Неждановой

Синтез искусств в жанре оперы-балета

Цель работы - исследовать взаимодействие и историческую роль музыкального, хореографического и драматического видов искусств в формировании синтетического жанра оперы-балета. Рассмотрение характерных признаков синтеза искусств базируется на основе анализа выдающихся образцов этого жанра и на его воплощении в современном культурном пространстве. Методология. Применен исторический, компаративный подходы и метод интердисциплинарного анализа, позволяющие определить трансформацию взаимодействия музыкального, сценического и танцевального компонентов жанра оперы-балета. Научная новизна исследования заключается в рассмотрении жанра оперы-балета в ракурсе межвидовых связей музыкального, танцевального и драматического искусств. Использование понятия сюитной танцевальной формы расширяет представления относительно обобщения генезиса и путей развития указанного жанра. Выводы. Анализ специфики знаковых образцов оперы-балета позволяет отметить, что этот особый жанр представляет уникальный синтез искусств, благодаря которому усиливается драматизм, углубляется характерность представления и рождается его новая образная целостность. Жанр оперы-балета дает возможность по-новому раскрыть художественные взаимосвязи различных творческих эпох. Успешные современные постановки свидетельствуют о его актуальности и жизнеспособности, а также открывают перспективы для дальнейшего развития.

Ключевые слова: синтез, опера-балет, сюитная танцевальная фрорма, комедия-балет, трагедия-балет, фантасмагория.

Statement of the problem. In addition to traditional performances, the basis of the repertoire of modern musical drama and opera theaters is represented by the various stage performances: art projects, musicals, rock operas, concert programs, etc. The current state of the development of musical and theatrical art requires from performers a universal combination of a high level of choreographic mastery, vocal and dra-

(c) Kaznacheieva T., 2018 
matic opportunities. The productions in which the synthesis of vocal, dance and stage arts is most vividly realized are extremely relevant and enjoy considerable popularity. An original discovery is the realization in modern conditions of the genre of opera-ballet, which has deep historical roots.

The study of the formation and initial development of the genre is of considerable interest to researchers. The fundamental work of V. Krasovskaya [5] is devoted to the history of the West-European ballet theater from the emergence of professional dance forms until the middle of the XVIII century. A. Bulycheva is the author of scientific works on the Baroque musical theater [4]. In the musicology literature, certain aspects of the ballet and opera of Jean-Baptiste Lully and Jean Philippe Rameau are analyzed [6, 9]. In V. Biyo's article, features of the theatrical practice of the opera-ballet "The Gallant of India" by J. P. Rameau [2] are considered. However, issues related to the specificity of the interaction of the musical, stage and dance components in the context of the opera-ballet genre remain little researched, which makes the article relevant.

The purpose of the work is to analyze the interaction and historical role of musical, choreographic and dramatic arts in the formation of the synthetic genre of opera-ballet.

Statement of the main material. A unique genre of opera-ballet originates in the Baroque epoch as a result of the fruitful activity of Italian and French choreographers. Let us note the peculiarity of the genre context of the West-European musical theater of the late XVI century, its diverse genre composition. At the specified time, the following types of theatrical works are developed: "ballet, heroic ballet, pantomime ballet, comedy, comedy-ballet, opera-comedy, divertissement, comic divertissement, eclogue, entre (exit), idyll, interlude, masquerade, opera, pastoral, comic pastoral, heroic pastoral, Italian pastoral, tragedy, tragicomedy, ballet-tragicomedy, opera-tragicomedy, opera-tragedy" [4, p. 15]. With all the variety of musical performances, it is possible to note such characteristic features as entertainment (masquerade, cavalcade, fireworks), the use of a sufficiently developed stage technique (carousels, decorative platforms, chariots). The play takes place in the open air; it involves a large number of ballet performers, singers, musicians, as well as courtiers, often headed by the king or queen.

A special place among such genre abundance belongs to the opera-ballet.

Its first example in the history of the world art is the opera-ballet "Circe", also referred to as the "Comedy ballet of the Queen". In October, 1581, a grandiose work devoted to the marriage of Marguerite of Lorraine, sister of Queen Louise, and the Duke de Joyeuse, consisting of a prologue and three interludes: "the first act with the ballet, choirs and apotheosis; the second act, which included singing, recitation, the procession of dryads, without dances, and the third action, which ended in a big ballet" was performed by the royal violinist, composer and dance master Baltazarini di Belgioioso in the Bourbon Hall of the Louvre in Paris. [8, p. 337].

As a model for this work, Baltazarini (as well as the future creators of the first operas) chose an ancient drama with singing and dancing. Actions are united by a single plot (the mythological story of the sorceress Circe), which was an undeniable innovation. In the title itself it can be noted that "ballet" is combined with "comedy", which is interpreted in this case as a dramatic play with a happy ending. The dance episodes are subordinated to a certain system (the queen's entrance, the presence of various processions, the unification of dancers in groups, the regulated movement in rows). It is quite difficult to determine the dominant component of the performance (word, dance or music). Together they form a model that is typical for its versatility, which for a long time defined the further development of the opera-ballet genre.

Another example of the synthesis of various arts, in which music, dance and literary work are combined, is presented in a new kind of musical and theatrical art - comedies-ballets (comédie-ballets). This variety is developed in the creative community of an outstanding French choreographer Pierre Beauchamp and composer Jean-Baptiste Lully. Lully began his works by composing ballets for court festivals, where he himself acted as a dancer [3, p. 78].

The plot of comedy-ballets was based on the classic comedies of Jean-Baptiste Moliere. Lully tended to fill his music with liveliness, expressiveness, and the variety of situations and characters of Molière [10, p. 780].

From the point of view of the structure of a composition, comedy-ballets were a series of interludes, divertissements and ballet entrances (Entrée). They are based on the following genre varieties: bourrée, galliard, gavotte, lure, minuet, chaconne, march, saraband. They often make up one whole suite of characteristic dances. Thus, dance episodes within the work form a suite dance form (the concept was introduced by us - T. K.).

13 plays by Moliere in the genre of comedy-ballet were staged in Paris. We shall note that some comedy-ballets are characterized by a satirical, even farcical orientation: "Monsieur de Pourceaugnac" (1669), "Le Bourgeois gentilhomme" (1670), etc.

In 1671, together with J.B. Moliere, P. Quinault, P. Corneille and J.B. Lully, P. Beauchamp stages a tragedy-ballet "Psyche" in the Tuileries Palace, and then at the Palais-Royal Theater. The original plan was to create a great opera-ballet. The basis of the five-act composition is the plot of an inserted novella from the antique novel of Apuleius "Metamorphoses" (or "Golden Ass") about the love of Cupid and Psyche.

A new, significant trend is that the ballet scenes, stage processions, mass dances form an important part of the overall drama are directly related to the plot. For example, at a certain point of the development of 
the tragedy, according to the dramatic task, the mourning dances (the end of the first act), the dances of furies in hell (the end of the fourth act), the wedding dance (the finale of the fifth act) appear in "Psyche". In the scenes where the action was transmitted to the dance, it had to "correspond to the complicated orchestral texture of the music with its dynamic change of tempo, to embody its impulse and its flexible grace" [5, p. 132].

The musical composition of J. B. Lully is marked by an original interpretation of musical forms: choir with ballet, aria accompanied by minuet, a duet with dances, and a combination of three instrumental ensembles.

Choreographic numbers inside the work are various in genre types (minuet, chaconne, march, etc.) and form a whole suite of characteristic dances. Thus, in the composition of the tragedy-ballet "Psyche" dance episodes form a suite dance form. This kind of suite dance form has a poly-genre basis, i.e. it unites a number of dances of independent meaning. Such a suite sequence of dance numbers does not imply their complex and contradictory interaction.

Quite often, "Psyche" is referred to the genre of the French lyrical tragedy. The work is connected with this particular type of French operas by a mythological plot and a composition consisting of a prologue and five acts. An analysis of the work is complicated by the lack of a single complete author's score (the edition of orchestral parties dates to 1720). The ballet and opera libretto, collections of vocal and instrumental numbers were published. On the basis of the extant sources, we can note that "Psyche", being the only example of a tragedy-ballet, in the unity of dramatic, musical and dance elements is closer to the genre of opera-ballet. The work develops the established traditions of the French musical theater, leading to the beginning of the formation of the national style of opera.

In 1671, in addition to the Royal Academy of Dance (Académie Royale de Danse), founded ten years earlier, with the permission of Louis XIV, the Royal Academy of Music (Académie Royale de Musique), the first French opera house, was opened in Paris. On the occasion of its opening, P. Beauchamp performed an opera-ballet "Pomone" (text by P. Perrin, music by R. Cambert).

"Pomone" - is a new page in the development of the opera-ballet genre. The work consists of a prologue and five acts, and is referred to the genre of musical pastoral. A new sample of the synthesis of words, music and dance focuses primarily on the merits of poetic text and pastoral music. The conversation for the first time was replaced by an operatic recitative, which had a specific characteristic form, based on the peculiarities of the French stage recitation (dimensionality, elevation, pathetic, connection of intonation and rhythm). Dance is a means which directs the development of the plot of the play, enlivening action and serving as its decoration.

The main tendencies of the formation of the synthetic musical-stage genres, laid by Jean-Baptiste Lully, are developed by his pupil Pascal Colasse in the performance "The Four Seasons" (1695).

The traditions of Baltazarini and P. Beauchamp in the genre of opera-ballet are continued by a French composer Jean Philippe Rameau. He created six samples in this specific synthetic genre, indicating the ways of the further development of the French ballet theater. As it was previously mentioned, the dance episodes of French musical and stage works of the early XVIII century from the point of view of the compositional structure often form a suite dance form. This trend of the genre is also evident in the operas-ballets of J.P. Rameau. Moreover, the musical plan of the dance scenes of the opera-ballets of the composer is characterized by its own content and structure. It is an independent genre layer, which is directly related to the style of the work. This feature determines a fundamentally new type of dramatic function of a dance.

Theatricality and the picturesque plasticity of the images are the distinctive properties of the musical style of J. P. Rameau. One of the most striking and interesting samples of the opera-ballet genre is "Les Indes galantes". The premiere of the work in the first edition took place in 1735.

In the third edition, the composition consists of four entrees, contains an expanded prologue with participation of allegorical heroes of the ancient myths.

The libretto by Louis Fuselier reflects the theme of interaction and contrast between the European and other cultures popular for the Enlightenment, allowing the composer to create a variety of images: lyric, dramatic, magical and pathetically exalted.

J.P. Rameau preserves and develops a characteristic structure of the operatic recitative, in which the recitation is modeled on the basis of the rhythm and pathos of the French language. Arioso forms are traditional, but the composer manages to achieve an exquisite ease within them.

The orchestra's part is expressive; the orchestration of the choreographic episodes is characterized by an abundance of orchestral colors emphasizing dramatic collisions. The composer uses a variety of instruments: strings, wind instruments (to which clarinet, horn, and bagpipes were added) and percussion instruments (kettledrum, tambourine).

The musical language is characterized by prepared melodic and harmonic turns, the presence of organ points, enharmonic modulations, static and expressive harmonies.

The originality and innovation of the opera-ballet "Les Indes galantes" led to numerous productions of the work both in the modern era for J. P. Rameau and in the XX century (in Paris, Florence, Bordeaux, New York) and XXI (in Zurich, Ferrara, Moscow). 
In the XVIII century, an inclination towards the genre of opera-ballet is developed in the works of George Frideric Handel. In the article about the dramatic functions of dance in the West European opera, it is noted that the composer skillfully uses the mastery of French ballet artists, paying them considerable attention [11, p. 100]. An outstanding French dancer Mademoiselle Marie Salle was a member of the ballet company of London's Covent Garden Theater. In 1734, in the opera "The Faithful Shepherd", which was revised by the composer, she performed the role of Terpsichore in the prologue, and in 1735, in the divertissement of the opera "Alcina" by G. F. Handel, besides the performance of the role of Cupid, she acted as a choreographer [1, p. 137]. M. Salle used choreographic and mimic elements to reveal the content of the play, which contributed to the manifestation of the organic connection of the dance with dramatic action.

In the XIX century, the development of the opera-ballet genre is associated with the formation of the integrity of the ballet and vocal mastery within the mythological, fantastic performances: "Le Villi" by G. Puccini (1884) and "Mlada" (N. Rimsky-Korsakov (1892).

In the XX century, in 1923, the opera-ballet "Padmavati" by Albert Roussel on the libretto of L. Lalua was staged in the Grand Opéra, by authentic modes and tunes, unusually recreating Indian atmosphere of the XIII century.

In the production of "The Miraculous Theater" (1948), a composer Hans Werner Henze, by artistic expressive means of the genre of opera-ballet, raises a question of the correlation between theatrical performance and reality.

The synthesis of the expressive potential of the performer in a unique work "Viy" by Vitaliy Sergeyevich Gubarenko based on the novel by Nikolai Gogol, staged in 2014 on the stage of the Odessa National Academic Opera and Ballet Theater, is transformed in a new way.

In this production opera-ballet (written by the composer in 1984) and choreographic scenes are masterfully composed. As a result of their organic connection, phantasmagoria is born - a genre of theatrical performance, in which a variety of bizarre images, fantasies, and visions are embodied in the grotesque form.

At the same time, it is possible to indicate a significant "increase in the ballet component and domination of the female, diabolical beginning in music" in the play [7, p. 54]. Fixing the predominance of the dance component, we shall emphasize that the scale dramatic action is born also due to the continuous interaction of musical drama, vocal and choral scenes.

The opera-ballet consists of a prologue and two acts. The stage action is marked by holistic development, the increase in dramatic tension leads to two climaxes.

In the prologue the main character of the play - Nikolai Gogol appears. Imagination of the writer gives rise to fantastic images. Their interaction is the basis for the scenic embodiment of the integral image of the entire opera and musical performance.

The first action consists of four scenes. The real characters (Homa, Sotnik, Dorosh, Cossack Sheptun, Bublichnitsa, etc.) sing; fantastic, mystical - dance (Gogol, Pannochka, Khoma's soul). A large-scale scene of the fair was marked by a bright national coloring. The climax of the action is represented by the news about the death of Pannochka, performed by the choir.

In the finale of the second action - there is the second climax - a spectacular scene of triumph of ominous otherworldly forces headed by Viy.

Thus, in the theatrical production of the opera-ballet "Viy", due to a new directing, staging, conducting, vocal, choreographic interpretation, a unique, original synthesis of musical, dramatic and dance arts is born.

Conclusions. From the standpoint of the XXI century, the evolution of the opera-ballet genre is of considerable interest. Consideration of the symbolic samples of the genre from the moment of its formation to modern works testifies to the transformation of the interaction of the musical, stage and dance components. Their correlation changed, the dominant role of one type of art was replaced by the predominance of the other one. In the compositional structure of many works of the genre of opera-ballet, we can note a suite dance form. Various embodiments of the opera-ballet have one common feature - due to the synthesis of various types of arts, dramatics of the play intensifies, the character of the performance deepens, and its new image integrity is formed in stage productions. A unique genre of opera-ballet gives an opportunity to reveal the artistic interrelations of various creative epochs in a new way. Successful modern productions testify to its viability, opening up new prospects for the further development.

\section{תimepamypa}

1. Барна И. Если бы Гендель вел дневник. Пер. с венгерского В. Тогобицкого. Будапешт: Корвина, 1972.

275 c.

2. Бійо В. Інтерпретація опери-балету Ж.-Ф. Рамо «Галантні Індії» на сучасному етапі. Київське музикознавство: зб. ст. НМАУ ім. П. І. Чайковського; КІМ ім. Р. М. Глієра. К., 2016. Вип. 54. С. 188-200.

3. Браудо Е. М. История музыки (сжатый очерк). 2-ое изд., испр. и доп. М.: Музгиз, 1935. 464 с.

4. Булычева А. В. Сады Армиды: Музыкальный театр французского барокко. М.: Аграф, 2004. 448 с.

5. Красовская В. М. Западноевропейский балетный театр: Очерки истории: От истоков до середины XVIII века. М.: Искусство, 1979. 295 с.

6. Малиньон Ж. Жан Филипп Рамо / пер. с фр. Д. Шен. Ленинград: Музыка, 1983. 124 с. 
7. Скляр В. И снова панночка летает, и взглядом остановит Вий..Фаворит удачи: ЧМП РИА «GMM пресс», 2014. Вип. 7 (52). С. 54-55.

8. Худеков С. Н. Искусство танца: История. Культура. Ритуал. М.: Эксмо, 2010. 544 с.

9. Ecorcheville J. De Lulli a Rameau 1690-1730 L'esthétique Musicale. Paris: Impressions Artistiques b.Marcel Forfin \& Cie. 1906. 172 p.

10. Grove G. Dictionary of Music and Musicians: in five volumes. New York-London: MACMILLAN \& Co., Ltd. Vol. II. 1906. 796 p.

11. Kaznacheeva T. Drama functions of a dance in the West-European opera (from J. Peri to Ch. V. Gluck). Biсник Національної академії керівних кадрів культури і мистецтва: наук. журнал. К.: Міленіум, 2017. № 3. С. $98-102$.

\title{
References
}

1. Barna, I. (1972). If Handel had a diary. Budapesht: Korvina [in Russian].

2. Biyo, V. (2016). Interpretation of opera-ballet J.-P. Ramo "Galant Indias" at the present stage. Kyivske muzykoznavstvo: zb. st. NMAU im. P. I. Chaikovskoho; KIM im. R. M. Hliiera, 54, 188-200 [in Ukrainian].

3. Braudo, E. M. (1935). History of music. Muzgiz [in Russian]. Russian].

4. Bulyicheva, A. V. (2004). Gardens of Armida: Music of the French Baroque theatre. Moscow: Agraf [in

5. Krasovskaya, V. M. (1979). Western European Ballet Theater: Essays on History: From the Beginning to the Mid-18th Century. Moscow: Iskusstvo [in Russian].

6. Malinon, Zh. (1983). Jean Philippe Rameau. (D. Shen, Trans). Leningrad: Muzyika [in Russian].

7. Sklyar, V. (2014). Again Pannochka flies and Viy will stop looking...Favorit udachi: ChMP RIA «GMM press», 7 (52), 54-55 [in Russian].

8. Hudekov, S. N. (2010). The art of dance: History. Culture. Ritual. Moscow: Eksmo [in Russian].

9. Ecorcheville, J. (1906). De Lulli a Rameau 1690-1730 L'esthétique Musicale. Paris: Impressions Artistiques b.-Marcel Forfin \& Cie [in French].

10. Grove, G. (1906). Dictionary of Music and Musicians: in five volumes. Vol. II. New York-London: MACMILLAN \& Co., Ltd. [in English].

11. Kaznacheeva, T. (2017). Drama functions of a dance in the West-European opera (from J. Peri to Ch. V. Gluck). Bulletin of the National Academy of Cultural and Arts Leaders, 3, 98-102 [in English].

Стаття надійшла до редакції 30.09.2018 p.

Удк 746.3(=161.2):75.052.036

\author{
Каленюк Ольга Миколаївна \\ кандидат педагогічних наук, доцент, \\ доцент кафедри образотворчого мистецтва \\ Східноєвропейського національного університету \\ імені Лесі Українки \\ ORCID 0000-0001-9618-6433 \\ konlyair@gmail.com
}

\section{ІНТЕРПРЕТАЦІЯ ТРАДИЦІЙНОЇ УКРАЇНСЬКОЇ ВИШИВКИ В СУЧАСНОМУ ПРОФЕСІЙНОМУ ПАННО}

\begin{abstract}
Мета роботи - доведення доцільності використання вишивки як традиційного виду українського декоративно-прикладного мистецтва у контексті сучасного професійного панно. Дослідження у даному напрямку дають поштовх до переосмислення мистецької спадщини, популяризують українську народну вишивку, мотивують молоде покоління митців до використання традиційних прийомів і технік у сучасних творчих проектах. Методологія дослідження базується на застосуванні загальнонаукових і спеціальних методів наукового пізнання та полягає у застосуванні історико-логічного, аналітичного, порівняльного, описового, систематизаційного методів. Теорії рецепції, семіотичного аналізу. Наукова новизна. У статті проведено аналіз трансформації декору панно в Україні XX - поч. XXI ст. Проаналізовано традиційні і сучасні прийоми формотворення сучасного панно. Виокремлено здобутки професійних українських та зарубіжних художників, викладачів і студентів мистецьких закладів України, творчість яких пов'язана з використанням вишивки в текстильних роботах. Визначено основні тенденції структури сучасного панно. Окреслено техніки традиційної української вишивки, які мають широкі перспективи для використання в художніх творах. Висновки. Доведено, що творчість сучасних українських митців декоративноприкладного мистецтва орієнтована на синтез матеріалів і трансформацію традиційних технік вишивки у площину декоративного панно, а також на пошук різних форм поєднання даної техніки з іншими матеріалами.
\end{abstract}

Ключові слова: декоративно-прикладне мистецтво; вишивка; синтез; панно; вишивальні техніки.

Каленюк Ольга Николаевна, кандидат педагогических наук, доцент кафредры изобразительного искусства Восточноевропейского национального университета имени Леси Украинки

Интерпретация традиционной украинской вышивки в современном профессиональном панно

Цель работы - доведение целесообразности использования вышивки как традиционного вида украинского декоративно-прикладного искусства в контексте современного профессионального панно. Исследования в данном направлении дают толчок к переосмыслению художественного наследия, будут популяризировать укра-

(C) Каленюк О. М., 2018 